DOI dx.doi.org/10.24866/7444-4825-7/283-288

М.В. Васина

Дальневосточный Федеральный Университет,

2. Владивосток

mashishya@mail.ru

\author{
КРУГЛЫЕ СТОЛЫ ПО БЕРЕГОВОЙ ТЕМАТИКЕ \\ НА КОНФЕРЕНЦИЯХ ТИХООКЕАНСКОГО ИНСТИТУТА \\ ГЕОГРАФИИ ДВО РАН
}

M.V. Vasina

Far-Eastern Federal University, Vladivostok

mashishya@mail.ru

\title{
ROUND TABLES ON THE COAST THEME \\ AT THE CONFERENCES OF THE PACIFIC INSTITUTE OF GEOGRAPHY OF THE FEB RAS
}

Ежегодно Тихоокеанским институтом географии ДВО РАН проводятся научно-практические конференции, посвященные всестороннему исследованию географических систем. Эти конференции дают возможность вынести на обсуждение проведенные комплексные исследования в области физической и экономической географии: применение практических методов и подходов в изучении территориальной и пространственной структуры геосистем, выявление проблем и перспектив развития территорий и акваторий Дальневосточного региона. В рамках конференции проходит также секция Круглого стола, посвященная проблемам и исследованиям береговой зоны и прибрежно-морского природопользования. Это направление в географии играет особую и очень важную роль в развитии Дальнего Востока России. Материалы конференций, затрагивающие тему исследования береговой зоны, отмечаются не только в рамках Круглого стола, но и в других разделах сборников материалов конференций, что говорит о том, насколько это важно с точки зрения экономической географии, природопользования, методологии географии. 
Для тематического анализа направлений развития прибрежноморского природопользования в 2017-2019 гг. использовались сборники материалов научно-практических конференций: «Геосистемы Северо-Восточной Азии: Территориальная организация и динамика» (Владивосток, 2017, 576 с.), «Геосистемы Северо-Восточной Азии: Типы, современное состояние и перспективы развития» (Владивосток, 2018, 674 с.) и «Геосистемы Северо-Восточной Азии: Особенности их пространственно-временных структур, районирование территории и акватории» (Владивосток, 2019, 582 с.). Конференции организованы при участии Дальневосточного отделения Российской академии наук, Дальневосточного федерального университета и Русского географического общества и проводятся на базе Тихоокеанского института географии.

Общее количество статей в каждом сборнике: 2017 - 118, 2018 129, 2019 - 107 статей.

В Сборник материалов конференции за 2017 г. включена часть: Материалы Круглого стола «Береговая зона Тихоокеанской России в 21 веке», в которой представлено 20 статей, в т. ч. одного автора - 12, коллектива авторов (от 2 до 8) - 8 работ, из них одна с международным участием. Вопросы прибрежного природопользования затронуты в 11 работах, теории и методологии - в двух, геоморфологические исследования - четырех, экологические вопросы - трех, истории освоения Дальнего Востока - в одной публикации.

В секции Круглого стола рассматриваются такие темы как «Типы и эволюция берегов дальневосточных морей» (Бровко, ДВФУ, c. 487), и более конкретно на примере «Геоморфология и эволюция лагунного озера Изменчивое (о. Сахалин)», (Бровко, Дзен, Малюгин, ДВФУ, с. 492). Даны характеристики островов залива Петра Великого в статье «Некоторые аспекты островного природопользования в Приморье» (Петренко, ДВФУ, с. 544).

Кроме того, как уже говорилось, вопросы природопользования в прибрежной зоне входят и в другие разделы публикаций конференции. Например, об экологической оценке окружающей среды в районе строительства порта Вера: «Актуальные аспекты радиоэкологи- 
ческого мониторинга в районе предполагаемого размещения угольного терминала «Порт Вера», (Кондратьев, ТИГ, с. 132); о восстановлении этапов развития ландшафтов полуострова Муравьева-Амурского и палеогеографических аспектах в исследовании развития лагунного озера в районе бухты Муравьиная: «Соотношение природных и антропогенных факторов в развитии геосистем полуострова МуравьеваАмурского» (коллектив авторов - Лящевская, Макарова и др., ТИГ, с. 137); о состоянии донного грунта в работе «Ландшафтная структура пролива Старка (залив Петра Великого)», (Мануйлов, ДВФУ, с. 143).

Bce упомянутые работы написаны приморскими авторами (за исключением совместного российско-вьетнамского доклада), из них 14 от Тихоокеанского института географии, 5 - от Дальневосточного федерального университета, 5 - их совместных работ, 1 - от Русского географического общества, 1 - от ОАО «Приморгражданпроект».

В Сборник научных статей Шестой Всероссийской научнопрактической конференции за 2018 год включены материалы Круглого стола «Прибрежно-морское природопользование: теория, методы, практика». В этом разделе 18 работ, посвященных теоретическим вопросам развития природопользования, районированию, изучению прибрежных ландшафтов: «Прибрежно-морское природопользование: вопросы терминологии» (Бровко, ДВФУ, с. 598); «Районирование береговой зоны тихоокеанской России по природным условиям хозяйственного освоения» (Каракин, ТИГ, с.601). Изучен район южного Приморья на предмет воздействия цунами, тайфунов, оползней в работе «Влияние аномальных природных процессов на состояние береговых геосистем и прибрежно-морское природопользование юга Дальнего Востока» (Лебедев, ТИГ, с. 612); результаты подводных исследований подробно показаны в работах «Ландшафты прибрежного мелководья Амурского залива» (Мануйлов, ДВФУ, с. 617) и «Геосистемы биогенных рифов залива Петра Великого» (Мануйлов, Петренко, ДВФУ, с. 622). Международное участие отмечают 3 работы, посвященные изучению динамики процессов у побережья Вьетнама, одна из них «Динамика побережья в дельте реки Красная (Тонкинский залив, Вьетнам)» (Нгуен Ван Кы, Ермошин, Ганзей и др., с. 640). 
Кроме того, в других разделах рассматриваются темы, касающиеся изучения берегов, например, «Геоморфологический каркас территории (на примере о. Рикорда, Приморский край), (Невский, ТИГ, с. 212). К актуальным вопросам освоения береговой зоны можно отнести и работу, посвященную экологии - «Перенос микропластика в прибрежно-морскую зону реками Южного Приморья», (Козловский, Качур, ТИГ, с. 486). В работе «Эколого-геоморфологические аспекты обеспечения транспортной безопасности в Приморском крае» (Коробов, Уткин и др., ТИГ, ТОИ, с. 490) рассмотрены природные и антропогенные процессы как факторы влияния на портовые и линейные объекты инфраструктуры.

Из них только 9 статей одного автора, 13 - коллективные работы (от 2 до 9 авторов).

Большая часть работ была представлена Тихоокеанским институтом географии ДВО РАН - 12, Дальневосточным федеральным университетом - 3; совместные работы Тихоокеанского института географии и вузов г. Ханой (Вьетнам) - 3, отдельно Институтом географии г. Ханой -1 , совместно Тихоокеанским институтом географии и Дальневосточным федеральным университетом - 1 , совместная работа университетов Владивостока, Москвы и Санкт-Петербурга - 1, Тихоокеанским океанологическим институтом ДВО РАН - 1 .

Сборник научных статей Седьмой научно-практической конференции за 2019 г. включает в себя материалы Круглого стола «Прибрежно-морское природопользование: теория, методы, практика». В этой секции 8 работ. За Круглым столом обсуждаются темы использования морских берегов - теоретические основы в статье «Подходы и принципы выделения территориальных и аква-территориальных сочетаний природных ресурсов» (Бакланов, ТИГ, с. 528); разнообразие берегов в работе «Лагунные берега Тихоокеанской России: морфология, эволюция, природопользование» (Бровко, Дзен, Жуковина, Малюгин, ДВФУ, с. 532), «К вопросу эволюции берегов Приморья» (Петренко, ДВФУ, с. 543); вопросы природопользования в работе «Сельскохозяйственные земли береговой зоны тихоокеанской России: современное состояние, динамика» (Каракин, ТИГ, с. 537); а 
также показательная статья по регионам «Динамика численности населения тихоокеанского побережья Дальнего Востока», (Ушакова, ТИГ, с. 568).

По береговым и подводным ландшафтам, островным территориям Дальнего Востока с экологической, рекреационной точки зрения в других разделах сборника материалов конференции представлено 13 работ. Уделяется внимание вопросам безопасности, связанным с берегами: «Привлечение палеоданных для изучения цунамиопасности населенного побережья Малых Курил» (Ганзей, Разжигаева и др., ТИГ, с. 41), «Типы берегов и проявление опасных береговых процессов на побережьях островов Русский и Шкота (залив Петра Великого, Японское море)», (Лебедев, с. 253). Использование природных ресурсов в рекреационных целях рассматривается в работах: «Водопады о. Итуруп как рекреационный ресурс» (Васина, ДВФУ, с. 157), «Подводные ландшафты рекреационного побережья бухты Троица (Мануйлов, ДВФУ, с. 273), «Геолого-геоморфологические памятники о. Сахалин как туристские объекты» (Меньчик, с. 279), «Памятники природы береговой зоны Охотского и Японского морей» (Семирякин, ДВФУ, с. 456). Приводятся результаты исследования островных территорий: «Ландшафтные исследования территории о. Русский» (Погорелов, Вовженяк, ДВФУ, ТИГ, с. 306); «Предварительные результаты обследования ландшафтов о. Рейнеке в 2017-2018 гг.», (Чипизубова, Базаров, ТИГ, с. 349). Социально-экономический подход в природопользовании и в распределении ресурсов использован в работе «Районирование российской части прибрежного региона Японского моря по сочетанию минеральных ресурсов» (Ткаченко, ТИГ, с. 484).

Большинство работ - 14 - заявлено Тихоокеанским институтом географии, 6 - Дальневосточным федеральным университетом, и одна их совместная работа.

Результаты исследований, представленные в сборниках материалов конференций, говорят о том, что роль географической науки в целом и береговедения в частности в Дальневосточном регионе очень важна, интересна и перспективна, привлекает все больше участников и объединяет в общих проектах разные организации, в том числе меж- 
дународные. В секции Круглого стола наблюдается некоторое снижение количества статей, но в целом эта тема всесторонне рассматривается в других разделах с теоретической, экономической, геоморфологической, рекреационной точек зрения. Исследования проводятся как детально, на отдельно выбранных объектах, так и представляются в виде общих закономерностей, выводов. Таким образом, конференции и Круглые столы дают возможность взаимодействия и передачи опыта ученых из разных организаций, регионов, стран, и создают оптимальные условия в решении проблем и определении перспектив развития географической науки на Дальнем Востоке. 